\title{
CYTOTOXIC ACTIVITY OF A MEDICINAL MANGROVE PLANT CERIOPS DECANDRA (GRIFF.) DING HOU LEAVES ON HUMAN BREAST ADENOCARCINOMA CELL LINE MCF-7
}

\author{
SUKASINI ${ }^{1 *}$, BHARGAV IYER $\mathbf{M}^{2}$ \\ ${ }^{1}$ Department of Pharmacology, SRM College of Pharmacy, SRM Institute of Science and Technology, Kattankulathur, Tamil Nadu, India. \\ ${ }^{2}$ Department of Pharmacology, Sri Ramakrishna College of Pharmacy, Dr. M. G. R. Medical University, Coimbatore, Tamil Nadu, India. \\ Email: s.sukasini@yahoo.in
}

Received: 05 March 2018, Revised and Accepted: 02 August 2018

ABSTRACT

Objective: Ceriops decandra (Griff.) Ding Hou (Rhizophoraceae) is an evergreen mangrove tree widely used in folklore medicine for the treatment of several diseases. Concerning the presence of anticancer molecule in $C$. decandra, the present investigation was carried out to study the preliminary phytochemical screening, in vitro cytotoxic effect, and apoptotic induction of methanol extract of $C$. decandra.

Methods: The preliminary phytochemical investigations were done using standard methods. Cytotoxic activity was analyzed in terms of brine shrimp (Artemia salina Leach) lethality bioassay. MTT (3-(4, 5-dimethylthiazol-2-yl)-2, 5-diphenyltetrazolium bromide) assay was used to evaluate the cell viability and growth inhibition of MCF-7 (human breast adenocarcinoma) cells after treatment with different doses of $C$. decandra extract. Cell morphological changes induced by the extract were observed using phase contrast inverted microscope. Induction of apoptosis was determined by DNA fragmentation assay.

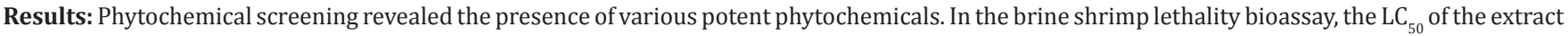
was found to be $12.5 \mu \mathrm{g} / \mathrm{mL}$, implying a promising cytotoxic effect. The MTT assay results showed increased inhibitory activity at a concentrationdependent manner and altered the cell morphology after exposure with $C$. decandra extract which exhibited typical apoptotic morphological changes. Furthermore, the characteristic DNA ladder pattern of $C$. decandra treated cells in agarose gel electrophoresis confirms the induction of apoptosis.

Conclusion: The research revealed the cytotoxic effect of $C$. decandra on MCF-7 cells through its nature of induction of apoptosis

Keywords: Ceriops decandra, Artemia salina, MCF-7 cell line, MTT assay, Apoptotic induction.

(C) 2018 The Authors. Published by Innovare Academic Sciences Pvt Ltd. This is an open access article under the CC BY license (http://creativecommons. org/licenses/by/4. 0/) DOI: http://dx.doi.org/10.22159/ajpcr.2018.v11i12.25635

\section{INTRODUCTION}

Marine floras such as sponges, microalgae, seaweeds, mangroves, and other halophytes are extremely potential source of anticancer drugs based on traditional knowledge and preliminary scientific work, but these are least explored [1]. The use of natural medicines has increased dramatically in the last decade. Even after the emergence of modern medicine, plants remain as the most important source of medicinal help. The natural medicines are considered as a popular choice by various segments of population due to their widespread availability and safety [2]. Most of the indigenous plant species, namely Ormocarpum sennoides (Willd.) DC [3], Heracleum maximum Bartr. [4], Senecio graveolens Wedd. [5], and Salicornia brachiata Roxb. [6] practiced worldwide by various traditional healers, and natural products such as Hypnea musciformis [7] and jadomycins [8] biosynthesized by the soil bacteria Streptomyces venezuelae are yet to be screened for its potential therapeutic effects.

Breast cancer is a disease in which malignant cancer cells form in the breast tissues which is the second overall cause of death among women. All people, whether male or female, are born with some breast cells and tissues that have the possibility to develop into cancer. However, breast cancer in men is rare, with only about 2190 diagnoses each year. There are two types of breast cancer tumors: Those that are non-cancerous or "benign," and those that are cancerous which are "malignant." The cancer cells of a malignant tumor spread to other parts of the body, usually through the lymph system and form a secondary tumor which results in metastatic breast cancer [9]. Currently, breast cancer treatments include surgery (lumpectomy and mastectomy), lymph node removal and analysis (sentinel lymph node biopsy and axillary lymph node dissection), reconstructive (plastic) surgery (implants and tissue flap procedures), external breast forms (prostheses), radiation therapy, systemic therapy, chemotherapy, hormonal therapy, targeted therapy, and osteoclast-targeted therapy [10]. However, these treatments can cause a lot of side effects to the patients and further damage their health. Therefore, there is a demand for alternative treatments with naturally derived anticancer agents.

Ceriops decandra (Griff.) Ding Hou [11] (Family: Rhizophoraceae) is being widely used in the traditional system of medicine. It is found in India, Bangladesh, Burma, Thailand, and Peninsular Malaysia [12]. It is known by different vernacular names such as Chiru kandal (Tamil), Gatharu (Telugu), Goran (Hindi), Bara goran (Bengali), and Gartah (Oriya) [13]. Conventionally, leaf and bark decoction applied externally to treat hemorrhage, indolent ulcers, hepatitis, and the juice of its fresh leaves was given to mothers in abdominal pain after childbirth as a postpartum remedy [14-16]. Scientific investigations have found out that leaves of $C$. decandra possess various pharmacological activities such as antioxidant [17], antidiabetic [18], anti-HIV [19], anti-SFV (Semliki Forest Virus) [20], antinociceptive [21], antimicrobial [22], antibacterial [23], as well as mangrove tea extract prepared from the leaves of $C$. decandra effectively prevented the dimethylbenz[a] anthracene (DMBA)-induced hamster buccal pouch carcinogenesis [24]. In addition to that, $C$. decandra contains anticancer molecule which is capable to fight against breast, bone marrow, and lung and blood cancers [25]. However, there is no evidence on the therapeutic effects of C. decandra in breast cancer.

Therefore, the present work aims to investigate the cytotoxic property and DNA fragmentation assay of $C$. decandra leaves on MCF-7 human 
breast adenocarcinoma cells which has not been previously studied and will help in dosage fixation for further exploration of their therapeutic efficacy.

\section{METHODS}

\section{Collection and authentication of plant material}

The leaves of $C$. decandra (Griff.) Ding Hou were collected from Pichavaram Mangrove Forest near Chidambaram, Tamil Nadu (India). The specimen was authenticated by Prof. P. Jayaraman, Botanist, Plant Anatomy Research Centre (PARC), West Tambaram, Chennai, Tamil Nadu (India), by specimen no. PARC/2015/3169 and has been deposited in the herbarium of the Department of Pharmacognosy, SRM College of Pharmacy, SRM Institute of Science and Technology, Kattankulathur, Tamil Nadu, India.

\section{Extraction procedure}

The leaves were washed, shade-dried, and powdered in a grinder mixer. About $70 \mathrm{~g}$ of the powdered leaves were placed in a stoppered container and soaked in $700 \mathrm{~mL}$ methanol for maceration at room temperature for about 7 days with occasional shaking. After 7 days, the resulting suspension was filtered and the solvent was evaporated to dryness under reduced pressure in rotary evaporator. Finally, the resultant extract was stored at $4^{\circ} \mathrm{C}$ in a refrigerator.

\section{Preliminary phytochemical analysis}

A small portion of the extract dissolved in its own mother solvent (methanol), and the obtained solution was used for the qualitative phytochemical tests by adopting standard procedures [26-30].

\section{Test for alkaloids}

Dragendorff's test

To a few ml of extract, 6 drops of Dragendorff's reagent (potassium bismuth iodide solution) were added. The formation of reddish-brown precipitate indicates the presence of alkaloids.

\section{Mayer's test}

To $1 \mathrm{~mL}$ of leaf extract, few drops of Mayer's reagent (potassium mercuric iodide solution) were added. Cream color precipitate was taken as indicative of the presence of alkaloids.

\section{Test for amino acids}

Ninhydrin test

To the test solution, add Ninhydrin solution and boil for few minutes. Formation of violet color indicates the presence of amino acids.

\section{Test for carbohydrates}

Molisch's test

To the test solution, add few drops of alcoholic $\alpha$-naphthol, then add few drops of concentrated sulfuric acid through sides of test tube - purple to violet color ring appears at the junction indicates the presence of carbohydrates.

\section{Test for flavonoids}

Shinoda test

To $2 \mathrm{~mL}$ of leaf extract, add few magnesium turnings and concentrated hydrochloric acid dropwise. A pink, scarlet, crimson red, or occasionally green to blue color appeared after few minutes confirms the presence of flavonoids.

\section{Test for steroids}

Salkowski test

Concentrated sulfuric acid was carefully added to the test solution to form lower layer. A reddish-brown color at the interface was taken as positive for steroid ring.

\section{Test for triterpenoids}

Liebermann-Burchard test

Treat the extract with few drops of acetic anhydride, boil and cool. Then, add concentrated sulfuric acid from the side of the test tube. Formation of deep red color indicates the presence of triterpenoids.

\section{Test for tannins (phenolic compounds)}

Ferric chloride test

$2-3$ drops of $10 \%$ ferric chloride solution were added to $2 \mathrm{~mL}$ of extract. The occurrence of blackish-blue color showed the presence of hydrolyzable tannins and a green-blackish color indicated the presence of condensed tannins.

\section{Test for glycosides}

To small amount of extract, add $1 \mathrm{~mL}$ water and shake well. Then, aqueous solution of sodium hydroxide was added. The formation of yellow color indicates the presence of glycosides.

\section{Test for anthraquinone glycosides}

Borntrager's test

Boil the leaf extract with $1 \mathrm{~mL}$ of sulfuric acid in a test tube for $5 \mathrm{~min}$. Filter while hot. Cool the filtrate and shake with equal volume of chloroform. Separate the lower layer of chloroform and shake it with half of its volume of dilute ammonia. A rose pink to red color is produced in the ammoniacal layer.

\section{Test for cardiac glycosides}

Keller-Killiani test

To the $5 \mathrm{~mL}$ of extract solution, add $2 \mathrm{~mL}$ of glacial acetic acid and 1 drop of ferric chloride solution. Transfer to a small test tube, add carefully $1 \mathrm{~mL}$ of concentrated sulfuric acid by the side of the test tube. Acetic acid layer shows blue color.

\section{Test for saponin glycosides}

Froth formation test

$2 \mathrm{ml}$ of leaf extract solution was mixed with water in a test tube and shaken well. Froth formation occurs which is stable for 15 min indicates the presence of saponin glycosides.

\section{Test for phlobatannin}

$5 \mathrm{~mL}$ of test solution was boiled with $2 \mathrm{~mL}$ of $1 \%$ aqueous hydrochloric acid - deposition of red precipitate indicates the presence of phlobatannin.

\section{Test for coumarin}

$3 \mathrm{~mL}$ of $10 \%$ sodium hydroxide was added to $2 \mathrm{~mL}$ of test solution. Formation of yellow color indicates coumarin.

\section{Test for emodin}

To $3 \mathrm{~mL}$ of leaf extract, add $2 \mathrm{~mL}$ of ammonium hydroxide and $3 \mathrm{~mL}$ of benzene. Formation of red color indicates the presence of emodin.

\section{Test for diterpenes}

Copper acetate test

The extract was dissolved in water and treated with 10 drops of copper acetate solution. Formation of emerald green color indicates the presence of diterpenes.

\section{Test for lactones}

Legal test

The extract was dissolved in pyridine and a mixture of sodium nitroprusside and sodium hydroxide solution was added. Deep red color indicates the presence of lactones. 
Test for lignin

Labat test

To the test solution, add few $\mathrm{ml}$ of gallic acid. The appearance of olive green color indicates the presence of lignin.

\section{Test for quinones}

$1 \mathrm{~mL}$ of the test solution was treated with alcoholic potassium hydroxide solution. Quinones give coloration ranging from red to blue.

\section{Test for resins}

$0.2 \mathrm{~g}$ of leaf extract was dissolved in $2 \mathrm{~mL}$ of distilled water and add $3 \mathrm{~mL}$ of copper sulfate solution. The solution was mixed well and allowed to separate. Formation of green color precipitate indicates the presence of resins.

\section{Brine shrimp lethality bioassay}

C. decandra extract was prescreened for cytotoxic activity using the brine shrimp lethality bioassay method and the lethal concentration, $50 \%\left(\mathrm{LC}_{50}\right)$ was determined [31,32]. Brine shrimp (Artemia salina Leach) eggs were collected from pet shops. Artificial seawater (38 gm sea salt dissolved in $1 \mathrm{~L}$ of distilled water) was taken in the small tank, and shrimp eggs were added into the larger compartment which was darkened, while the smaller compartment was illuminated. 2 days were allowed to hatch and to be matured as nauplii. Constant oxygen supply was carried out through the hatching time. The hatched shrimps attracted to the light (phototaxis) and so nauplii free from eggshell were collected from the illuminated part of the tank. $32 \mathrm{mg}$ of dried methanolic extract of $C$. decandra were taken and dissolved in $200 \mu \mathrm{L}$ of pure dimethyl sulfoxide (DMSO), and finally, the volume was made to $20 \mathrm{~mL}$ with seawater. The solution was then serial diluted to $100,50,25$, 12.5 , and $6.25 \mu \mathrm{g} / \mathrm{mL}$ with seawater. Then, $2.5 \mathrm{~mL}$ of each concentration of plant extract solution was added to $2.5 \mathrm{~mL}$ of seawater containing 10 nauplii. With the help of a Pasteur pipette, 10 living shrimps were

Table 1: Phytochemical composition of methanol extract of C. decandra leaves

\begin{tabular}{ll}
\hline Phytoconstituents & Methanol extract \\
\hline Alkaloids & + \\
Amino acids & + \\
Carbohydrates & + \\
Flavonoids & + \\
Steroids & + \\
Triterpenoids & + \\
Tannins (phenolic compounds) & + \\
Glycosides & + \\
Anthraquinone glycosides & + \\
Cardiac glycosides & - \\
Saponin glycosides & + \\
Phlobatannin & + \\
Coumarin & + \\
Emodin & + \\
Diterpenes & + \\
Lactones & + \\
Lignin & + \\
Quinones & + \\
Resins & + \\
\hline
\end{tabular}

C. decandra: Ceriops decandra dropped into each test tube. A drop of dry yeast suspension $(3 \mathrm{mg}$ in $5 \mathrm{~mL}$ artificial seawater) was added as food to each test tube and maintained under illumination. After $24 \mathrm{~h}$, the test tube was inspected using a magnifying glass, and the count of surviving nauplii in each tube had noted down. After that, the percentage of lethality and lethal concentration $\left(\mathrm{LC}_{50}\right)$ was calculated.

\section{Cell line and culture}

Human breast adenocarcinoma (MCF-7) cell line was obtained from Veterinary College, Vepery, Chennai, Tamil Nadu (India). The cells were maintained in minimal essential medium (MEM) supplemented with $10 \%$ FBS, penicillin $(100 \mathrm{U} / \mathrm{mL})$, and streptomycin $(100 \mu \mathrm{g} / \mathrm{mL})$ in a humidified atmosphere of $50 \mu \mathrm{g} / \mathrm{mL} \mathrm{CO}_{2}$ at $37^{\circ} \mathrm{C}$.

\section{Reagents}

MEM was purchased from Hi-Media Laboratories; fetal bovine serum (FBS) was purchased from Cistron laboratories; trypsin, methylthiazolyldiphenyl-tetrazolium bromide (MTT), and DMSO were purchased from Sisco research laboratory chemicals, Mumbai, India. All of other chemicals and reagents were obtained from Sigma-Aldrich, Mumbai, India.

MTT (3-(4, 5-dimethylthiazol-2-yl)-2, 5-diphenyltetrazolium bromide) assay

Human breastadenocarcinoma (MCF-7) cells were tested against different doses of $C$. decandra extract. Viability of the cells and growth inhibition was assessed by MTT assay [33,34]. MCF-7 cells $\left(1 \times 10^{5} /\right.$ well $)$ were plated in 24-well plates and incubated at $37^{\circ} \mathrm{C}$ with $5 \% \mathrm{CO}_{2}$ condition. After the cell reaches the confluence, the sample was added and incubated for $24 \mathrm{~h}$. After incubation, the sample was removed from the well and washed with phosphate-buffered saline (pH 7.4) or MEM without serum. $100 \mu \mathrm{L} /$ well $(5 \mathrm{mg} / \mathrm{mL})$ of $0.5 \%$ 3-(4, 5-dimethyl-2-thiazol-2-yl)-2, 5-diphenyltetrazolium bromide (MTT) was added and incubated for $4 \mathrm{~h}$. After incubation, $1 \mathrm{~mL}$ of DMSO was added in all the wells. The absorbance at $570 \mathrm{~nm}$ was measured with UV spectrophotometer using DMSO as the blank. Measurements were performed and the concentration required for a $50 \%$ cell inhibition $\left(\mathrm{IC}_{50}\right.$ ) was determined graphically. The percentage of cell viability and percentage of cell inhibition were calculated using the following formulas:

$$
\begin{aligned}
& \% \text { cell viability }=\mathrm{A} 570 \text { of treated cells } / \mathrm{A} 570 \text { of control cells } \times 100 \\
& \% \text { cell inhibition }=100 \% \text { cell viability }
\end{aligned}
$$

$\mathrm{IC}_{50}$ was determined by plotting a graph using the percentage of cell inhibition at $\mathrm{Y}$-axis and log concentration in X-axis. A line drawn from $50 \%$ value on the $\mathrm{Y}$-axis meets the curve and interpolate to the $\mathrm{X}$-axis. The $\mathrm{X}$-axis value gives the log concentration. The antilog of that value gives the $\mathrm{IC}_{50}$ value. The $\mathrm{IC}_{50}$ value (the concentration of a test compound causing $50 \%$ effect) was used as a parameter for cytotoxicity.

\section{Morphological analysis}

To determine the changes induced by the extract from MTT assay, the morphological observations were done using inverted microscope with the cells treated with different concentrations of $C$. decandra.

\section{DNA fragmentation assay}

Apoptosis induced by the $C$. decandra extract was examined by analyzing DNA fragmentation in human breast adenocarcinoma

Table 2: Effect of methanol extract of $C$. decandra on brine shrimp lethality bioassay

\begin{tabular}{lllllll}
\hline Conc. $(\boldsymbol{\mu g} / \mathbf{m L})$ & Log conc. & Total nauplii & Number of nauplii dead & Number of nauplii live & \% $\mathbf{m o r t a l i t y}$ & $\mathbf{L C} \mathbf{C}_{50}(\boldsymbol{\mu g} / \mathbf{m L})$ \\
\hline 6.25 & 0.79 & 10 & 04 & 06 & 40 & $12.5(\mu \mathrm{g} / \mathrm{mL})$ \\
12.5 & 1.09 & 10 & 05 & 05 & 50 & \\
25 & 1.39 & 10 & 06 & 04 & 60 & \\
50 & 1.69 & 10 & 07 & 03 & 80 & \\
100 & 2.00 & 10 & 08 & 02 & 80 & \\
\hline
\end{tabular}


(MCF-7) cells using agarose gel electrophoresis [35]. Dispense $0.5 \mathrm{~mL}$ of cell suspension (cancer cells). Centrifuge cells at $\times 200 \mathrm{~g}$ at $4^{\circ} \mathrm{C}$ for $10 \mathrm{~min}$. Add to the pellet $0.5 \mathrm{~mL}$ of TTE solution and vortex vigorously. This procedure allows the release of fragmented chromatin from nuclei, after cell lysis (due to the presence of Triton X-100 in the TTE solution) and disruption of the nuclear structure (following $\mathrm{Mg}^{++}$chelation by EDTA in the TTE solution). To separate fragmented DNA from intact chromatin, centrifuge tubes at $\times 20,000 \mathrm{~g}$ for $10 \mathrm{~min}$ at $4^{\circ} \mathrm{C}$. Carefully remove the supernatants and add $500 \mu \mathrm{L}$ of TTE solution into the pellet. Add $500 \mu \mathrm{L}$ of ice-cold $\% \mathrm{M} \mathrm{NaCl}$ and vortex vigorously. The addition of the salt will be able to remove histones from DNA. Add $700 \mu \mathrm{L}$ of ice-cold isopropanol and vortex vigorously. Allow precipitation to proceed overnight at $-20^{\circ} \mathrm{C}$. After precipitation, recover DNA by pelleting for $10 \mathrm{~min}$ at $\times 20,000 \mathrm{~g}$ at $4^{\circ} \mathrm{C}$. Rinse the pellets by adding 500-700 $\mu \mathrm{L}$ of ice-cold $70 \%$ ethanol. Centrifuge tubes at $\times 20,000 \mathrm{~g}$ for $10 \mathrm{~min}$ at $4^{\circ} \mathrm{C}$. Dissolve DNA by adding $20-50 \mu \mathrm{L}$ of TE solution to each tube and place the tubes at $4^{\circ} \mathrm{C}$. Mix the samples of DNA with loading buffer by adding $\times 10$ loading buffer to a final concentration of $\times 1$. The addition of loading buffer to samples allows to load in wells more easily and to monitor the run of samples. Run the electrophoresis in standard Tris EDTA buffer after setting the voltage to the desired level. During electrophoresis, it is possible to monitor the migration of samples by following the migration of bromophenol blue dye contained in the loading dye. Stop the electrophoresis when the dye reaches about $3 \mathrm{~cm}$ from the end of the gel. To visualize DNA, place the gel on a UV transilluminator.

\section{RESULTS}

\section{Preliminary phytochemical analysis}

The result of the phytochemical analysis conducted on $C$. decandra extract was given in Table 1. Of 19 phytochemical groups investigated, except saponin glycosides other 18 phytoconstituents, namely alkaloids, amino acids, carbohydrates, flavonoids, steroids, triterpenoids, tannins (phenolic compounds), glycosides, anthraquinone glycosides, cardiac glycosides, phlobatannin, coumarin, emodin, diterpenes, lactones, lignin, quinones, and resins were present in the methanol extract of C. decandra.

\section{Brine shrimp lethality bioassay}

The cytotoxicity of the methanolic extract of $C$. decandra was investigated by brine shrimp (A. salina leach) lethality bioassay. The secondary metabolites of the leaves of $C$. decandra exhibited significant toxicity against Artemia nauplii. Mortality increased linearly with increase in concentration of $C$. decandra extract (Table 2). The $\mathrm{LC}_{50}$ value for methanol extract was found to be $12.5 \mu \mathrm{g} / \mathrm{mL}$ (Fig. 1). According to Meyer's toxicity index, herbal extracts with $\mathrm{LC}_{50}$ value lower than $1000 \mu \mathrm{g} / \mathrm{mL}$ are considered as toxic. The cytotoxic activity exhibited by the methanol extract of $C$. decandra was promising, and this clearly indicates the presence of potent bioactive cytotoxic compounds.

MTT (3-(4, 5-dimethylthiazol-2-yl)-2, 5-diphenyltetrazolium bromide) assay

The cytotoxic activity of methanol extract of $C$. decandra on MCF-7 cell line was determined by the MTT assay. The multiple concentrations of methanolic extract of $C$. decandra were used and effective doses had calculated from dose-response curve. As a result of incubation, it was found that as the extract concentration increases, the number of viable cells decreases and increases the growth inhibition (Fig. 2). It was found that the methanol extract of $C$. decandra exhibited significant activity against the MCF-7 cell line with an $\mathrm{IC}_{50}$ value of $62.5 \mu \mathrm{g} / \mathrm{mL}$ which was shown in Fig. 3. The cytotoxic compound presents in the C. decandra arrest further growth of MCF-7 cells and decreases the cell viability.

\section{Morphological analysis}

Morphological alterations of MCF-7 cells after treatment with the C. decandra extract were observed under inverted microscope. The observations (Fig. 4) showed the morphological changes such as

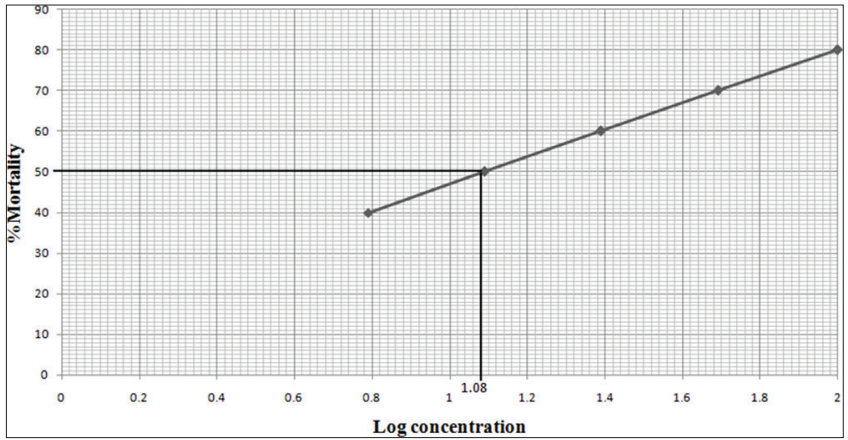

Fig. 1: Determination of $\mathrm{LC}_{50}$ value for the methanolic extract of Ceriops decandra - Linear correlation between log concentration versus percentage mortality

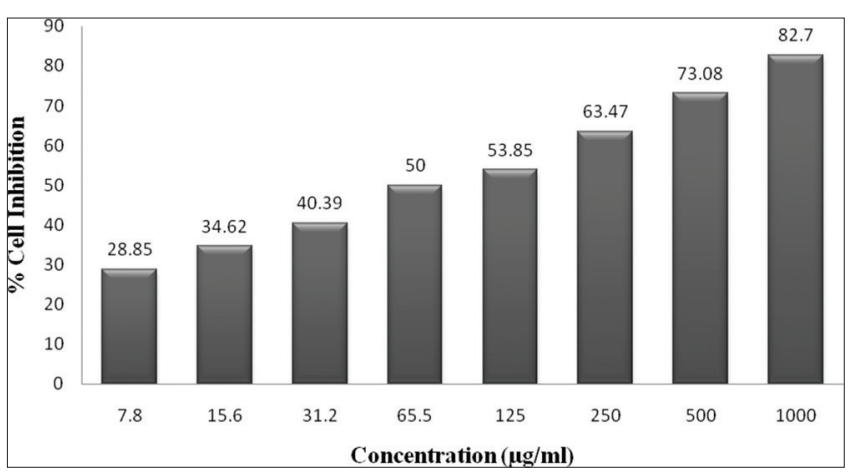

Fig. 2: Cytotoxic effect of methanol extract of Ceriops decandra on MCF-7 cell line

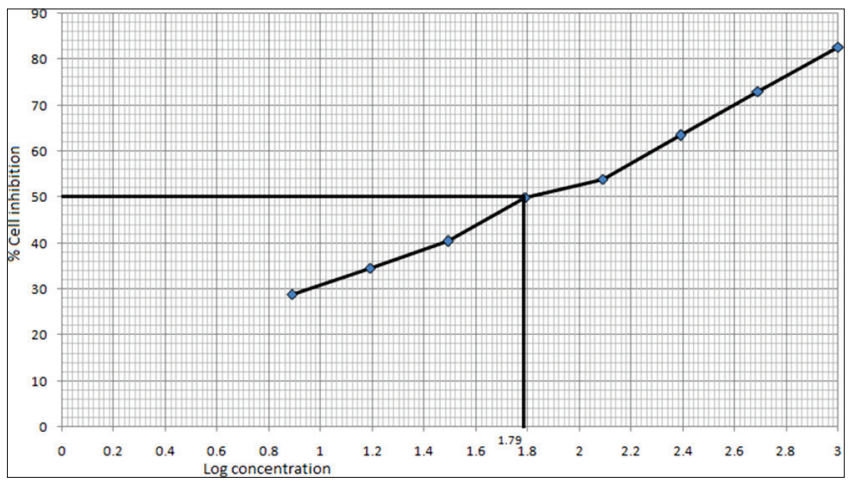

Fig. 3: Determination of $\mathrm{IC}_{50}$ value for the methanolic extract of Ceriops decandra - Linear correlation between log concentration versus percentage cell inhibition

rounding, detachment, shrinkage, and membrane blebbing in MCF7 cells. These suggested that $C$. decandra may induce apoptotic cell death in MCF-7 (human breast adenocarcinoma) cells.

\section{DNA fragmentation assay}

DNA fragmentation is a technique which is used to detect the extensive DNA fragmentation-induced during apoptosis. The ladder-like DNA fragmentation is qualitative indicator of apoptosis. DNA fragmentation is obtained by gel electrophoresis with different concentrations of the methanolic extract of $C$. decandra performed on MCF-7 cell line. The DNA migrated as discrete bands which is compared to DNA marker, gave a ladder of approximately 100 base pair (bp). Such DNA ladders are considered to be a hallmark of apoptosis; continue smears may also indicate DNA fragmentation due to apoptosis. It is found that methanolic extract showed internucleosomal DNA cleavage produces ladder pattern at concentration of $125 \mu \mathrm{g} / \mathrm{mL}$ and $62.5 \mu \mathrm{g} / \mathrm{mL}$ (Fig. 5). 


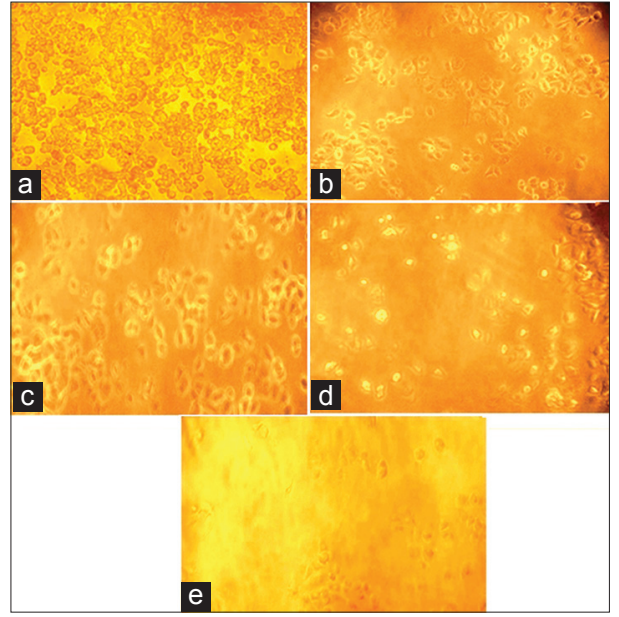

Fig. 4: Morphological changes on MCF-7 (human breast adenocarcinoma) cells after treatment with different concentrations of methanolic extract of Ceriops decandra (a) normal MCF-7 cells (untreated cells), (b) $62.5 \mu \mathrm{g} / \mathrm{mL}$, (c) $125 \mu \mathrm{g} / \mathrm{mL}$, (d) $250 \mu \mathrm{g} / \mathrm{mL}$, (e) $1000 \mu \mathrm{g} / \mathrm{mL}$

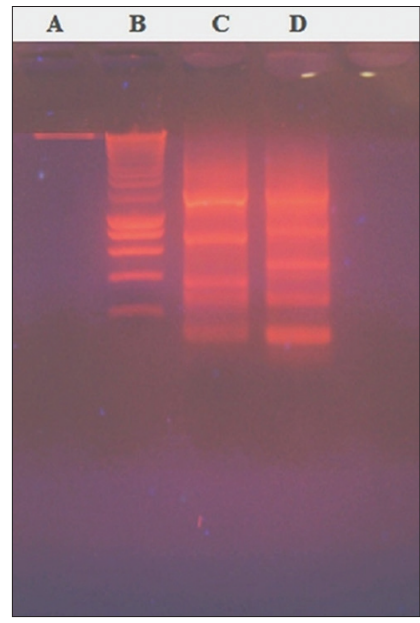

Fig. 5: DNA laddering visualized in agarose gel by bromophenol blue dye staining of methanolic extract of Ceriops decandra (a) control, (b) marker - 100bp, (c) concentration of $125 \mu \mathrm{g} / \mathrm{mL}$, (d) concentration of $62.5 \mu \mathrm{g} / \mathrm{mL}$

This indicates that the DNA fragmentation was detected which is a typical feature of apoptosis.

\section{DISCUSSION}

In summary, the scientific claim that $C$. decandra has anticancer properties on breast cancer has been partially validated by investigating cytotoxic effect of $C$. decandra leaves extract on brine shrimp (A. salina Leach) and MCF-7 cells. Currently, C. decandra has only been tested on breast cancer cells. Its effect on other cancer cell types (bone marrow and lung and blood cancers) have yet to be determined [25]. To the best of our knowledge, this is the first report describing the cytotoxic effect induced by the methanolic extract of $C$. decandra on MCF-7 cells. The mangrove plants that belong to the genus Ceriops have shown enormous ethnomedicinal potential; however, few reports are available for its various potential therapeutic effects. $C$. decandra and Ceriops tagal are widely distributed in the Pichavaram mangrove forest. Of two mangrove species of Tamil Nadu, C. decandra remains unexplored than $C$. tagal. C. decandra is a salt tolerant plant and possesses unique bioactive metabolites. Lupane-triterpene esters and other triterpene constituents have been isolated from the leaves of $C$. decandra [36,37].
Previous studies have shown the effective oral cancer treatment with $1.25 \%$ of $C$. decandra leaves black tea extract on DMBA-induced hamster buccal pouch carcinoma [24]. On comparing, here, $C$. decandra shows the significant cytotoxic activity with least concentration on brine shrimp and MCF-7 cells and also triggers apoptosis. Taken together, the cytotoxic effect induced by $C$. decandra in MCF-7 cells can be mechanistically linked to apoptotic initiation. More research needs to be done on elucidating the mechanism between the active ingredients and molecular targets involved in the regulation of cell cycle and in vivo efficacy of $C$. decandra on animal models.

\section{CONCLUSION}

The data obtained in this study demonstrated that the methanolic extract of mangrove plant $C$. decandra possesses cytotoxic properties and also acts as apoptotic inducer in MCF-7 human breast adenocarcinoma cells which can be used as alternative treatment for breast cancer

\section{CONFLICTS OF INTEREST}

The authors do not have conflicts of interest.

\section{REFERENCES}

1. Sithranga Boopathy N, Kathiresan K. Anticancer drugs from marine flora: An overview. J Oncol 2010;2010:214186.

2. Richard CL, Jurgens TM. Effects of natural health products on blood pressure. Ann Pharmacother 2005;39:712-20.

3. Sukasini S, Iyer MB, Priyadarsini SS, Kumar PR. Retrospect of Ormocarpum sennoides (Willd.) DC: A boon to phytomedicine. Glob J Res Med Plants Indig Med 2015;4:203-8.

4. Webster D, Taschereau P, Lee TD, Jurgens T. Immunostimulant properties of Heracleum maximum bartr. J Ethnopharmacol 2006;106:360-3.

5. Echiburú-Chau C, Alfaro-Lira S, Brown N, Salas CO, Cuellar M, Santander J, et al. The selective cytotoxicity elicited by phytochemical extract from Senecio graveolens (Asteraceae) on breast cancer cells is enhanced by hypoxia. Int J Oncol 2014;44:1357-64.

6. Santhanakrishnan D, Perumal RK, Kanth SV, Rao JR, Chandrasekaran B. Antioxidant and cytotoxic effects of methanolic extract of Salicornia brachiata L. In Hepg2 cells. Int J Res Pharm Sci 2013;4:512-7.

7. Pandian A, Baskaran K, Subashini R. Free radical scavenging and antioxidant properties of marine red algae Hypnea musciformis. Int $\mathrm{J}$ Pharm Pharm Sci 2015;7:227-31.

8. Hall SR, Blundon HL, Ladda MA, Robertson AW, Martinez-Farina CF, Jakeman DL, et al. Jadomycin breast cancer cytotoxicity is mediated by a copper-dependent, reactive oxygen species-inducing mechanism. Pharmacol Res Perspect 2015;3:e00110.

9. National Breast Cancer.org. Available from: http://www. nationalbreastcancer.org/about-breast-cancer.

10. Cancer.Net. Available from: http://www.cancer.net/cancer-types/breastcancer/treatment-options.

11. The Wealth of India: A Dictionary of Indian Raw Materials and Industrial Products. Vol. 3. New Delhi: Council of Scientific and Industrial Research Publisher; 1992. p. 445

12. Duke N, Kathiresan K, Salmo III S G, Fernando E S, Peras J R, Sukardjo S, Miyagi T, et al. Ceriops decandra. IUCN Red List Threat Species 2010;2010:e.T178853A7627935.

13. Sukasini S, Iyer MB, Affrin MF, Chakradhar NB, Kumar PR. Pharmacognostic and physiochemical standardisation of leaves of Ceriops decandra (Griff.) ding hou. World J Pharm Res 2016;5:1833-43.

14. Quattrocchi U. CRC World Dictionary of Medicinal and Poisonous Plants: Common Names, Scientific Names, Eponyms, Synonyms and Etymology. Ceriops Arn. Rhizophoraceae. Florida, United States: CRC Press, Taylor and Francis Group; 2016. p. 897.

15. Ray T. Customary use of mangrove tree as a folk medicine among the Sundarban resource collectors. Int J Res Human Arts Lit 2014;2:43-8.

16. Salini G. Pharmacological profile of mangrove endophytes-a review. Int J Pharm Pharm Sci 2015;7:6-15.

17. Nagababu P, Rao VU. Phytochemical, antibacterial and antioxidant evaluation of Ceriops decandra (Griff.) Ding Hou leaf extract. J Chem Pharm Res 2014;6:428-37.

18. Nabeel MA, Kathiresan K, Manivannan S. Antidiabetic activity of the mangrove species Ceriops decandra in alloxan-induced diabetic rats. J Diabetes 2010;2:97-103.

19. Premanathan M, Nakashima H, Kathiresan K, Rajendran N, 
Yamamoto N. In vitro anti human immunodeficiency virus activity of mangrove plants. Indian J Med Res 1996;103:278-81.

20. Premanathan M, Kathiresan K, Chandra K. Antiviral evaluation of some marine plants against Semliki forest virus. Int J Pharm 1995;33:75-7.

21. Uddin SJ, Shilpi JA, Barua J, Rouf R. Antinociceptive activity of Ceriops decandra leaf and pneumatophore. Fitoterapia 2005;76:261-3.

22. Bakshi M, Chaudhuri P. Antimicrobial potential of leaf extracts of ten mangrove species from Indian Sundarban. Int J Pharm Biol Sci 2014;5:294-304

23. Selvam KA, Kolanjinathan K. Antibacterial activity of mangrove medicinal plants against gram positive bacterial pathogens. Int J Adv Res Biol Sci 2014;1:234-41.

24. Sithranga Boopathy N, Kandasamy K, Subramanian M, You-Jin J. Effect of mangrove tea extract from Ceriops decandra (Griff.) Ding Hou. On salivary bacterial flora of DMBA induced hamster buccal pouch carcinoma. Indian J Microbiol 2011;51:338-44.

25. Akbar S. Chemical from Mangroves may Help Fight Cancer. The Times of India; 2015. Available from: http:/www.timesofindia.indiatimes. $\mathrm{com} / \mathrm{city} / \mathrm{hyderabad} / \mathrm{Chemical-from-mangroves-may-help-fight-}$ cancer/articleshow/47635754.cms.

26. Kokate CK, Purohit AP, Gokhale SB. Pathway to Screen Phytochemical Nature of Natural Drugs. Pharmacognosy. $49^{\text {th }}$ ed. Pune: Nirali Prakashan; 2014. p. A.22-7.

27. Godghate A, Sawant R, Sutar A. Phytochemical analysis of ethanolic extract of roots of Carrisa carandus Linn. Rasayan $\mathrm{J}$ Chem 2012;5:456-9.

28. Poonkothai M, Selvi S. Phytochemical screening and antioxidant assay of Agaricus bisporous (White Button Mushroom). Int J Biol Pharm Res
2015;6:877-84.

29. Rathore SK, Bhatt S, DhyaniS, Jain A. Preliminary phytochemical screening of medicinal plant Ziziphus mauritiana Lam. Fruits. Int J Curr Pharm Res 2012;4:160-2.

30. Sridhar N, Duggirala SL, Puchchakayala G. Analyzing the phytochemical composition of Justicia neesii Ramam. J Phytopharm 2014;3:348-52.

31. Meyer BN, Ferrigni NR, Putnam JE, Jacobsen LB, Nichols DE, McLaughlin JL, et al. Brine Shrimp: A convenient general bioassay for active plant constituents. Planta Medica 1982;45:31-4.

32. Asaduzzaman MD, Rana S, Hasan SM, Hossain M, Nittananda DA. Cytotoxic (Brine Shrimp Lethality Bioassay) and antioxidant investigation of Barringtonia acutangula (L.). Int J Pharm Sci Res 2015;6:1179-85

33. Mosmann T. Rapid colorimetric assay for cellular growth and survival: Application to proliferation and cytotoxicity assays. J Immunol Methods 1983;65:55-63.

34. Kavitha K. Evaluation of total phenols, total flavonoids, antioxidant and anticancer activity of Mucuna pruriens seed extract. Asian J Pharm Clin Res 2018;11:242-6.

35. Wyllie AH. Glucocorticoid-induced thymocyte apoptosis is associated with endogenous endonuclease activation. Nature 1980;284:555-6.

36. Perez J, Shen CC, Ragasa CY. Triterpenes from Ceriops decandra (griff.) W. Theob. Asian J Pharm Clin Res 2017;10:244-6.

37. Ponglimanont $\mathrm{C}$, Thongdeeying $\mathrm{P}$. Lupane-Triterpene esters from the leaves of Ceriops decandra (Griff.) Ding Hou. Aust J Chem 2005;58:615-8. 